\title{
Determining the Best Poloxamer Carrier for Thiocolchicoside Solid Dispersions
}

\section{Tiyokolşikosid Katı Dispersiyonları için En İyi Poloksamer Taşıyıcının Belirlenmesi}

\author{
(D) Hemanth ANNEPOGU1, (D) Hindustan Abdul AHAD2*, (D) Devanna NAYAKANTI3 \\ 1Jawaharlal Nehru Technological University, Research and Development, Ananthapuramu, India \\ 2Raghavendra Institute of Pharmaceutical Education and Research (RIPER), Department of PG Industrial Pharmacy, Ananthapuramu, India \\ 3Jawaharlal Nehru Technological University, Oil Technological and Pharmaceutical Research Institute, Ananthapuramu, India
}

\section{ABSTRACT}

Objectives: The aim of this study of this study was to discover the best poloxamer as a solid dispersion carrier for thiocolchicoside (TCS).

Materials and Methods: The compatibility of TCS with excipients was studied by differential scanning colorimetry and fourier transform infrared spectroscopy. Different formulations of solid dispersions (SDs) were made with poloxamer carriers, i.e. poloxamer-108, poloxamer-188, poloxamer-237, poloxamer-338, and poloxamer-407 were made by taking TCS:poloxamer in ratios of 1:1, 1:2, 1:4, and 1:6. The SDs were made by a novel microwave fusion method and compressed using an 8-station tablet compression machine. The fabricated SD tablets were characterized by physicochemical constraints and drug release rates. The release of TCS from the prepared SDs was later analyzed by kinetic models.

Results: TCS was observed to be compatible with the poloxamer carriers. The SD formulations showed satisfactory physicochemical constraints and TCS release following first-order release.

Conclusion: Among the poloxamer carriers used, poloxamer-188 was the best for increasing the solubility and release rate of TCS from the SDs.

Key words: Thiocolchicoside, poloxamer, solid dispersion, evaluation

öz

Amaç: Bu çalışmanın amacı tiyokolşikosid için en iyi poloksamer katı dispersiyon taşıyıcısını bulmaktır.

Gereç ve Yöntemler: Tiyokolşikosidin eksipiyanlarla geçimliliği diferansiyel tarama kolorimetrisi ve fourier transform infrared spektroskopisi ile çalışılmıştır. Katı dispersiyonların (SD) farklı formülasyonları poloksamer-108, poloksamer-188, poloksamer-237, poloksamer-338 ve poloksamer-407 gibi poloksamer taşıyıcılarını tiyokolşikosid: poloksamer oranı 1:1, 1:2, 1:4 ve 1:6 olacak șekilde yapılmıștır. SD'ler yeni bir mikrodalga füzyon metoduyla yapılmıştır ve 8-istasyonlu tablet kompresyon makinesi kullanılarak basılmıştır. Üretilen SD tabletleri fizikokimyasal kısıtlama ve ilaç salım oranları ile karakterize edilmiştir. Hazırlanan SD'lerden salınan tiyokolşikosid daha sonra kinetik modellerle analiz edilmiştir.

Bulgular: Tiyokolşikosid poloksamer taşıyıcılarla geçimli bulunmuştur. SD formülasyonları fizikokimyasal kısıtlamalar açısından ve tek basamaklı salımı takiben tatmin eden tiyokolşikosid salmı göstermiştir.

Sonuç: Kullanılan poloksamer taşıyıcılar arasında, poloksamer-188 çözünürlük artışı ve SD'lerde tiyokolşikosid salımı açısından en iyisi olarak belirlenmiştir.

Anahtar kelimeler: Tiyokolşikosid, poloksamer, katı dispersiyon, değerlendirme 


\section{INTRODUCTION}

Industrial pharmacists make many attempts to enhance the solubility of drugs economically. Among the various approaches for enhancing solubility, the solid dispersion (SD) approach is gaining in importance as it is simpler and requires less effort than the other approaches.

Thiocolchicoside (TCS) is a colchicoside derivative from Gloriosa superba and Colchicum autumnale. TCS is a muscle relaxant used to tackle sore muscle shrinkages, acute and arthritic problems, and pains, and it lacks sedative side effects, unlike other muscle relaxants. It is also given with many nonsteroidal anti-inflammatory drugs. ${ }^{2-5}$ TCS is a yellow crystalline powder that is slightly soluble in ethyl alcohol and insoluble in chloroform.

The traditional method of preparing SDs is by fusion, in which the polymer-carriers used for SDs are not exposed to a uniform heat from the heat source. To overcome this, a novel microwave (MW) melting technique is adopted. Electromagnetic irradiation was applied in an MW oven with 0.3 to $300 \mathrm{GHz}$ of infrared and radio frequencies equivalent to wavelengths of $1 \mathrm{~mm}$ to $1 \mathrm{~m}$. This technique can be adopted for obtaining fast and continuous heating even in materials presenting low heat conductivity (e.g., polymers), because the relocation of energy does not depend on heat diffusion. ${ }^{6,7}$ Thus, this novel MW melting method was adopted in the preparation of SDs.

Much research has been performed on enhancing the solubility of drugs using poloxamers, i.e. poloxamer-108, ${ }^{8}$ poloxamer-188, ${ }^{9}$ poloxamer-237,10 poloxamer-338, ${ }^{11}$ and poloxamer-407.12

Therefore, it is important to enhance the solubility of TCS, with faster discharge, absorption, and action to relieve acute patients. It also helps researchers to know which poloxamer carrier is best for releasing TCS among poloxamer-108, poloxamer-188, poloxamer-237, poloxamer-338, and poloxamer-407. The current investigation aimed to enhance the solubility of TCS with poloxamer carriers and find out the best among the better poloxamers.

\section{MATERIALS AND METHODS}

\section{Materials}

TCS was gifted from Yarrow Chemicals. Poloxamer-108, poloxamer-188, poloxamer-237, poloxamer-338, and poloxamer-407 were from Amrutha Organics, Hyderabad. Microcrystalline cellulose, talc, and magnesium stearate were obtained from Colorcon, India. Double distilled water (DW) was utilized whenever appropriate.

\section{Statistical analysis}

Solubility studies

Pure TCS was examined for solubility in $0.1 \mathrm{~N} \mathrm{HCl}$, water, $\mathrm{pH}$ 4.5 acetate buffer, and $\mathrm{pH} 6.8$ and $\mathrm{pH} 7.4$ phosphate buffers. ${ }^{13}$

\section{Drug-excipient compatibility studies}

Differential scanning calorimetry (DSC) and fourier transform infrared (FTIR) spectroscopy were used to explore the interaction among the TCS and carriers used in the study.

\section{Differential scanning calorimetry}

Pure drug (TCS) and 1:1 ratio of TCS and carriers (SDs) were included in the analysis. About $10 \mathrm{mg}$ of mix (in a DSC aluminum pan) was examined between 50 and $300^{\circ} \mathrm{C}$ (DSC-50, Shimadzu, Japan).

\section{Fourier transform infrared spectroscopic study}

The relations between the ingredients of the SDs were investigated using FTIR spectroscopy. The FTIR spectra of the TCS alone and together with carriers were logged using an FTIR spectrometer (Bruker) by scanning at $4000-400 \mathrm{~cm}^{-1}$ range.

\section{Designing of solid dispersions (physical mixture)}

TCS and carrier SDs were prepared by MW induced heating technique. ${ }^{14}$ Different percentages of TCS and carrier (Table 1) were put into a glass beaker in CATA- 2R MW oven (Catalytic Systems, Pune, India) at 560 W. In the oven, one beaker containing drug excipient blend was kept in an accurate site every time. The mixture was exposed to MW radiation for prearranged periods $(3,4,5$, and $6 \mathrm{~min})$. Then the beakers with mixtures were left at room temperature to solidify. ${ }^{15}$ The SDs were kept in a desiccator for $24 \mathrm{~h}$ and smashed in a mortar. The pulverized blends were passed through an $80 \#$ sieve (Table 1).

\section{Table 1. Drug (thiocolchicoside):carrier (poloxamer) ratios in} various formulations

\begin{tabular}{|c|c|c|}
\hline Drug:carrier & Ratio & Formulation code \\
\hline \multirow[t]{4}{*}{ TCS: poloxamer-108 } & $1: 1$ & TP108-1 \\
\hline & $1: 2$ & TP108-2 \\
\hline & $1: 4$ & TP108-3 \\
\hline & $1: 6$ & TP108-4 \\
\hline \multirow[t]{4}{*}{ TCS: poloxamer-188 } & $1: 1$ & TP188-1 \\
\hline & $1: 2$ & TP188-2 \\
\hline & $1: 4$ & TP188-3 \\
\hline & $1: 6$ & TP188-4 \\
\hline \multirow[t]{4}{*}{ TCS: poloxamer-237 } & $1: 1$ & TP237-1 \\
\hline & $1: 2$ & TP237-2 \\
\hline & $1: 4$ & TP237-3 \\
\hline & $1: 6$ & TP237-4 \\
\hline \multirow[t]{4}{*}{ TCS: poloxamer-338 } & 1:1 & TP338-1 \\
\hline & $1: 2$ & TP338-2 \\
\hline & $1: 4$ & TP338-3 \\
\hline & $1: 6$ & TP338-4 \\
\hline \multirow[t]{4}{*}{ TCS: poloxamer-407 } & $1: 1$ & TP407-1 \\
\hline & $1: 2$ & TP407-2 \\
\hline & $1: 4$ & TP407-3 \\
\hline & $1: 6$ & TP407-4 \\
\hline
\end{tabular}

TCS: Thiocolchicoside 


\section{Evaluation of solid dispersions}

Flow properties for solid dispersions

The designed SDs were evaluated in terms of their micromeritic characteristics, i.e. angle of repose, true and tapped densities, Carr's index, and the Hausner ratio. ${ }^{16,17}$

Yield

The \% recovery of SDs were determined after full removal of moisture. Thus it includes the weight of dried SDs in the total of the TCS and excipients necessary for making SDs.

$\%$ Yield $=\frac{\text { Actual weight of the SDs }}{\text { Total weight of the TCS and excipients }} \times 100$

Tablet preparation and depiction

SDs equivalent to TCS were made by direct compression ${ }^{18}$ into tablets, after mixing with prerequisite amounts of all ingredients (Table 2) with the aid of a tablet compression machine ( 8 station-Karnavati Engineering, Ahmedabad, India).

\section{Evaluation of tablets}

The following parameters were tested for the TCS SDs tablets. ${ }^{19-22}$

\section{Morphological constraints}

The tablets were assessed for their uniformity in size and shape.

\section{Thickness}

The thickness of the tablets was measured using vernier calipers (Qumos Enterprises, Mumbai, India). They were measured three times.

\section{Hardness}

The force needed to fragment the tablets was recorded with a Monsanto tablet hardness tester (Vinsyst Technologies, Mumbai) to determine the physical strength. These tests were performed three times.

\section{Uniformity in weight}

Individual lots of 20 tablets were weighed with an electronic digital balance (Citizen, CY-104, Mumbai, India) and the mean was determined. The $\%$ change in weight was determined and then compared with IP specifications (limit $\pm 7.5 \%$ ).

\section{Table 2. formulation of a tablet containing solid dispersions}

\begin{tabular}{ll} 
Ingredients & Quantity per tablet $(\mathbf{m g})$ \\
\hline SDs equivalent to $4 \mathrm{mg}$ of TCS & 125 \\
\hline Lactose & 50 \\
\hline Starch & 15 \\
\hline Microcrystalline cellulose & 50 \\
\hline Magnesium stearate & 5 \\
\hline Talc & 5 \\
\hline The weight of the tablets & 250 \\
\hline
\end{tabular}

SDs: Solid dispersions, TCS: Thiocolchicoside

\section{Friability}

This test was done with a Roche Friabilator to determine the physical strength of the prepared tablets and to check their intactness when subjected to physical stresses. $W_{\text {initial }}$ was recorded for 10 tablets before the test, and they were placed in the drum and spun at $25 \mathrm{rpm}$ for 4 min and $W_{\text {final }}$ was recorded. The loss on friability was then determined by the following equation:

$\mathrm{F}=\frac{\text { Winitial }- \text { Wfinal }}{\text { Winitial }} \times 100$

\section{Thiocolchicoside calibration curve}

The practice of finding TCS by ultraviolet (UV) spectrophotometer at $259 \mathrm{~nm}$ was standardized and the TCS was observed to obey the Beer-lambert law in $2-10 \mu \mathrm{g} / \mathrm{mL}$ concentration. ${ }^{23}$

\section{Uniformity of thiocolchicoside content}

Tablets from every lot $(n=5)$ were taken, weighed, and smashed in a mortar. Then $4 \mathrm{mg}$ of TCS was dissolved in $100 \mathrm{~mL}$ of 0.1 $\mathrm{M} \mathrm{HCl}$. Next, $0.2 \mathrm{~mL}$ of solution was made up to $10 \mathrm{~mL}$ with 0.1 $\mathrm{M} \mathrm{HCl}$. The absorbance was determined ${ }^{24}$ at $259 \mathrm{~nm}$ with a UVvisible spectrophotometer (Double Beam-lab India, Mumbai). The content evenness was determined from the TCS standard calibration graph.

Dissolution rate/in vitro thiocolchicoside discharge

The dissolution conditions were as below: ${ }^{25}$

- Apparatus: USP XXIII dissolution test apparatus

- Dissolution medium: $0.1 \mathrm{M} \mathrm{HCl}$

- Volume: $900 \mathrm{~mL}$

- Temperature: $37 \pm 0.5^{\circ} \mathrm{C}$

- Paddle speed: 50 rpm

- Sampling times: every $5 \mathrm{~min}$

- Sample withdrawn: $10 \mathrm{~mL}$

- Absorbance: $259 \mathrm{~nm}$

\section{Kinetic modeling of TCS discharge}

The mechanisms of the TCS discharge from the tablets were examined and the rate kinetics of the SDs was attained with the formula shown below: ${ }^{26,27}$

- Cumulative \% of drug discharged vs time (zero-order plots)

- Log cumulative \% of drug enduring vs time (first-order plots)

- Cube root of drug remaining vs time (Hixson-Crowell plots)

\section{Accelerated stability studies}

The TCS-SDs tablets were subjected to stability studies for 6 months in different storage environments to determine their sustainability in these storage conditions (Environmental Chamber Model 5532). ${ }^{28}$

\section{RESULTS}

Novel and efficient SDs of TCS with poloxamer carriers using MW fusion (MWF) were prepared. In contrast, TCS matching with the carriers used was confirmed by the DSC thermograms (Figure 1). 
The matching of the TCS drug with the poloxamer carriers was established by FTIR studies and the FTIR spectra of the TCS with poloxamer carriers used (Figure 2).

The SDs were checked for flow properties to confirm their free movement from hopper to tableting machine die wall without adhesion. The flow properties of the fabricated TCS-SDs are given in Table 3.

The fabricated TCS tablets were observed to be uniform in size and shape, off white, and odorless with a smooth surface. The prepared formulations' thickness, uniformity of weight, hardness, friability, percent yield, and TCS amount uniformity are given in Table 4.

The main reason for preparing SDs is to increase the solubility of drugs. The solubility of the prepared SDs was studied in various solvents. The solubility of the prepared tablets was high in $\mathrm{DW}$ and $0.1 \mathrm{~N} \mathrm{HCl}$. These values are shown in Figure 3.

Later TCS discharge was assessed by in vitro drug dissolution. The TCS discharge from the tablets was determined by plotting a calibration curve of TCS as per the procedure described before and the calibration curve (Figure 4).

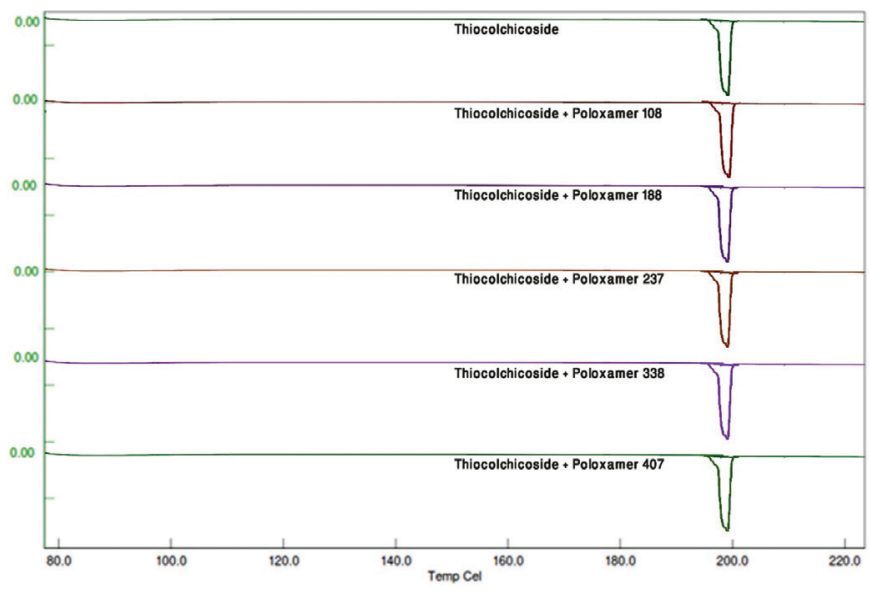

Figure 1. DSC thermograms of thiocolchicoside with poloxamer bases DSC: Differential scanning calorimetry

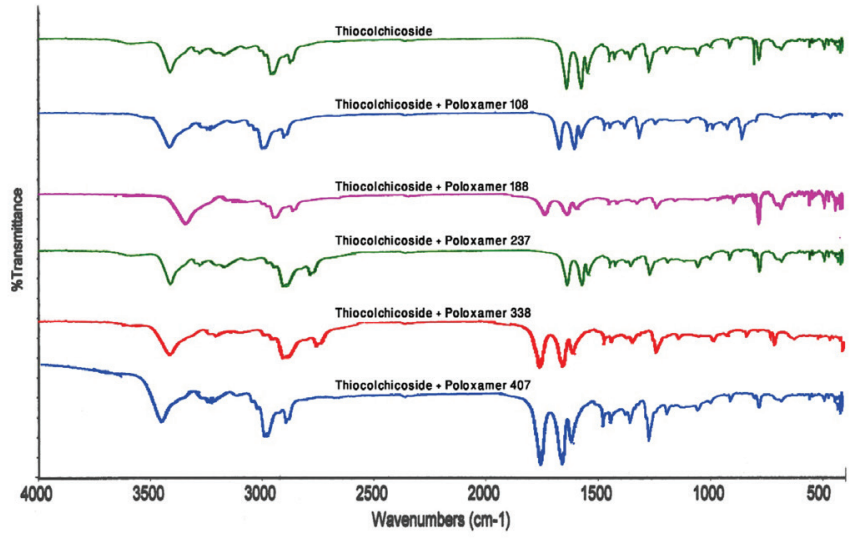

Figure 2. FTIR spectrum of thiocolchicoside with poloxamer FTIR: Fourier transform infrared
The solubility of TCS SDs was further demonstrated by in vitro testosterone dissolution studies. All the SDs showed satisfactory drug discharge. The SDs containing TCS:poloxamer (1:6) showed better discharge than the other formulations (Figure 5).

The TCS discharge mechanism from the tablets was determined by kinetic treatment of in vitro drug dissolution data. The correlation $\left(R^{2}\right)$ values are given in Table 5. The first-order and Hixson-Crowell's plots are shown in Figures 6 and 7.

\section{DISCUSSION}

DSC is a vital tool for obtaining evidence quickly about suitability among the TCS and the carrier by the presence, swing, or vanishing of endothermic/exothermic peaks. ${ }^{29}$ DSC gives an insight into the melting and recrystallization activities of SDs. Neither loss of characteristic peaks nor appearance of new peaks were documented upon DSC analyses and confirms the lack of incompatibility between the TCS and the carrier used. ${ }^{30}$ The DSC points were attained on pure TCS and physical blend. The thermograms of TCS with poloxamer combinations were shifted towards the left, indicating proper impregnation of TCS with the carriers used. The characteristic peaks and stretches of pure TCS were also seen in the TCS-poloxamer carrier combinations, indicating no incompatibility of TCS with the carriers used.

FTIR spectroscopy is another significant approach to determine possible chemical interactions among TCS and the excipients. The orientation of new absorption bands gives the main signals of the interaction among TCS and the active substance. ${ }^{31}$ The FTIR spectra showed that typical TCS bands and carrier separately were not rehabilitated in the mixtures, which indicates no interactions between TCS and poloxamer.

The spectra of TCS show prominent bands at $1556.6 \mathrm{~cm}^{-1}$, attributed to the $\mathrm{C}=\mathrm{O}$ stretching, tropane ring at $1647.6 \mathrm{~cm}^{-1}$, Amide II band ( $\mathrm{N}-\mathrm{H}$ stretching) at $3326.98 \mathrm{~cm}^{-1}$, and $-\mathrm{OH}$ stretching band at $3413.77 \mathrm{~cm}^{-1}$. All these bands were seen undisturbed even in TCS-poloxamer blends and are given in Figure 2.

The free flow of SDs from the hopper was confirmed by the micromeritic properties. The fabricated TCS SDs showed very good flow properties in terms of the angle of repose $\left(34.52 \pm 0.02\right.$ to $\left.25.21 \pm 0.03^{\circ}\right)$ and nearly spherical particles. The compressibility index was $0.877 \pm 0.05$ to $10.552 \pm 0.09$, signifying good compression properties while tableting. The fabricated TCS tablets were uniform in size and shape, off white, and odorless, with a smooth surface.

The TCS tablets appeared to be uniform in thickness $(4.5 \mathrm{~mm}$ ) and weight, indicating the TCS and excipients used were added and blended properly. The loss on friability was $<1 \%$ and the hardness was more than $4 \mathrm{~kg} / \mathrm{cm}^{2}$, indicating that the tablets have good mechanical strength, and that means good cohesive properties of SDs for compressing them into tablets. The yield was observed to be good (>90\%) and TCS content was uniform.

Pure TCS was checked for solubility in various media, i.e. water, $0.1 \mathrm{~N} \mathrm{HCl}, \mathrm{pH} 4.5$ acetate buffer, pH 6.8 phosphate buffer, and 
Table 3. Flow character specifications

\begin{tabular}{|c|c|c|c|c|c|}
\hline & Flow properties & & & & \\
\hline Formulation & Angle of repose $\left(^{\circ}\right)$ & Bulk density & Tapped density & Carr's index & Hausner ratio \\
\hline TP108-1 & $33.95 \pm 0.03$ & $0.785 \pm 0.05$ & $0.799 \pm 0.06$ & $1.752 \pm 0.01$ & $1.017 \pm 0.01$ \\
\hline TP108-2 & $29.64 \pm 0.05$ & $0.458 \pm 0.02$ & $0.466 \pm 0.01$ & $1.716 \pm 0.08$ & $1.017 \pm 0.01$ \\
\hline TP108-3 & $28.45 \pm 0.02$ & $0.635 \pm 0.01$ & $0.654 \pm 0.06$ & $2.905 \pm 0.02$ & $1.029 \pm 0.02$ \\
\hline TP108-4 & $29.05 \pm 0.05$ & $0.258 \pm 0.01$ & $0.268 \pm 0.01$ & $3.731 \pm 0.05$ & $1.038 \pm 0.01$ \\
\hline TP188-1 & $27.37 \pm 0.09$ & $0.528 \pm 0.03$ & $0.536 \pm 0.04$ & $1.492 \pm 0.01$ & $1.015 \pm 0.01$ \\
\hline TP188-2 & $31.22 \pm 0.06$ & $0.568 \pm 0.07$ & $0.578 \pm 0.04$ & $1.730 \pm 0.03$ & $1.017 \pm 0.03$ \\
\hline TP188-3 & $31.55 \pm 0.05$ & $0.258 \pm 0.01$ & $0.268 \pm 0.01$ & $3.731 \pm 0.07$ & $1.038 \pm 0.09$ \\
\hline TP188-4 & $25.84 \pm 0.06$ & $0.269 \pm 0.05$ & $0.287 \pm 0.02$ & $6.271 \pm 0.05$ & $1.066 \pm 0.05$ \\
\hline TP237-1 & $26.37 \pm 0.05$ & $0.356 \pm 0.03$ & $0.398 \pm 0.01$ & $10.552 \pm 0.09$ & $1.117 \pm 0.01$ \\
\hline TP237-2 & $30.50 \pm 0.05$ & $0.524 \pm 0.05$ & $0.545 \pm 0.03$ & $3.853 \pm 0.04$ & $1.040 \pm 0.03$ \\
\hline TP237-3 & $29.41 \pm 0.03$ & $0.425 \pm 0.03$ & $0.457 \pm 0.01$ & $7.002 \pm 0.09$ & $1.075 \pm 0.03$ \\
\hline TP237-4 & $29.15 \pm 0.04$ & $0.546 \pm 0.04$ & $0.555 \pm 0.06$ & $1.621 \pm 0.05$ & $1.016 \pm 0.07$ \\
\hline TP338-1 & $30.50 \pm 0.06$ & $0.365 \pm 0.05$ & $0.389 \pm 0.02$ & $6.169 \pm 0.06$ & $1.065 \pm 0.08$ \\
\hline TP338-2 & $29.12 \pm 0.06$ & $0.358 \pm 0.01$ & $0.364 \pm 0.02$ & $1.648 \pm 0.01$ & $1.016 \pm 0.01$ \\
\hline TP338-3 & $25.21 \pm 0.03$ & $0.452 \pm 0.03$ & $0.456 \pm 0.05$ & $0.877 \pm 0.05$ & $1.008 \pm 0.01$ \\
\hline TP338-4 & $26.09 \pm 0.06$ & $0.254 \pm 0.08$ & $0.259 \pm 0.01$ & $1.930 \pm 0.01$ & $1.019 \pm 0.07$ \\
\hline TP407-1 & $26.27 \pm 0.04$ & $0.524 \pm 0.01$ & $0.541 \pm 0.03$ & $3.142 \pm 0.02$ & $1.032 \pm 0.02$ \\
\hline TP407-2 & $30.28 \pm 0.06$ & $0.658 \pm 0.05$ & $0.666 \pm 0.01$ & $1.201 \pm 0.01$ & $1.012 \pm 0.01$ \\
\hline TP407-3 & $34.52 \pm 0.02$ & $0.524 \pm 0.05$ & $0.566 \pm 0.01$ & $7.420 \pm 0.09$ & $1.080 \pm 0.08$ \\
\hline TP407-4 & $28.46 \pm 0.02$ & $0.425 \pm 0.01$ & $0.433 \pm 0.01$ & $1.847 \pm 0.01$ & $1.018 \pm 0.01$ \\
\hline
\end{tabular}

All values given as mean $\pm S D$, trials $(n=3)$, SD: Standard deviation

Table 4. Physical characteristics of prepared solid dispersions

\begin{tabular}{|c|c|c|c|c|c|c|}
\hline TP108-1 & $250.2 \pm 2.01$ & $6.5 \pm 0.21$ & $4.50 \pm 0.01$ & $0.18 \pm 0.02$ & $88.2 \pm 0.85$ & $102.5 \pm 1.23$ \\
\hline TP108-3 & $255.2 \pm 0.12$ & $6.9 \pm 0.08$ & $4.50 \pm 0.03$ & $0.53 \pm 0.04$ & $90.5 \pm 0.94$ & $99.5 \pm 0.77$ \\
\hline TP108-4 & $255.2 \pm 0.98$ & $5.3 \pm 0.06$ & $4.51 \pm 0.04$ & $0.45 \pm 0.03$ & $99.2 \pm 0.32$ & $100.6 \pm 0.48$ \\
\hline TP188-3 & $252.3 \pm 0.96$ & $5.7 \pm 0.01$ & $4.50 \pm 0.04$ & $0.53 \pm 0.03$ & $97.8 \pm 1.95$ & $96.2 \pm 0.06$ \\
\hline TP188-4 & $253.8 \pm 0.08$ & $6.3 \pm 0.02$ & $4.51 \pm 0.06$ & $0.55 \pm 0.04$ & $98.6 \pm 3.26$ & $99.0 \pm 2.25$ \\
\hline TP237-1 & $250.5 \pm 0.17$ & $5.3 \pm 0.03$ & $4.50 \pm 0.02$ & $0.61 \pm 0.01$ & $95.6 \pm 0.68$ & $100.6 \pm 0.08$ \\
\hline TP237-2 & $250.1 \pm 0.07$ & $4.5 \pm 0.04$ & $4.50 \pm 0.06$ & $0.82 \pm 0.01$ & $92.5 \pm 0.84$ & $97.1 \pm 0.84$ \\
\hline TP338-2 & $252.3 \pm 0.10$ & $4.5 \pm 0.01$ & $4.51 \pm 0.03$ & $0.72 \pm 0.01$ & $90.7 \pm 0.83$ & $98.5 \pm 0.09$ \\
\hline TP338-3 & $251.2 \pm 0.54$ & $7.2 \pm 0.07$ & $4.52 \pm 0.08$ & $0.63 \pm 0.02$ & $97.4 \pm 0.64$ & $97.8 \pm 0.75$ \\
\hline TP338-4 & $250.2 \pm 1.28$ & $8.3 \pm 0.04$ & $4.50 \pm 0.03$ & $0.25 \pm 0.03$ & $98.3 \pm 0.88$ & $96.6 \pm 0.84$ \\
\hline TP407-1 & $250.2 \pm 2.26$ & $4.5 \pm 0.03$ & $4.51 \pm 0.05$ & $0.41 \pm 0.03$ & $92.8 \pm 1.23$ & $98.9 \pm 0.99$ \\
\hline TP407-2 & $251.2 \pm 2.39$ & $4.2 \pm 0.02$ & $4.52 \pm 0.03$ & $0.52 \pm 0.01$ & $96.8 \pm 1.29$ & $100.9 \pm 2.25$ \\
\hline TP407-3 & $250.1 \pm 1.25$ & $6.3 \pm 0.01$ & $4.50 \pm 0.04$ & $0.53 \pm 0.03$ & $97.9 \pm 0.36$ & $97.8 \pm 0.23$ \\
\hline TP407-4 & $252.1 \pm 1.24$ & $5.2 \pm 0.01$ & $4.51 \pm 0.03$ & $0.65 \pm 0.07$ & $99.1 \pm 0.35$ & $99.6 \pm 0.09$ \\
\hline
\end{tabular}

All values given as mean $\pm S D$, trials $(n=3)$, SD: Standard deviation 


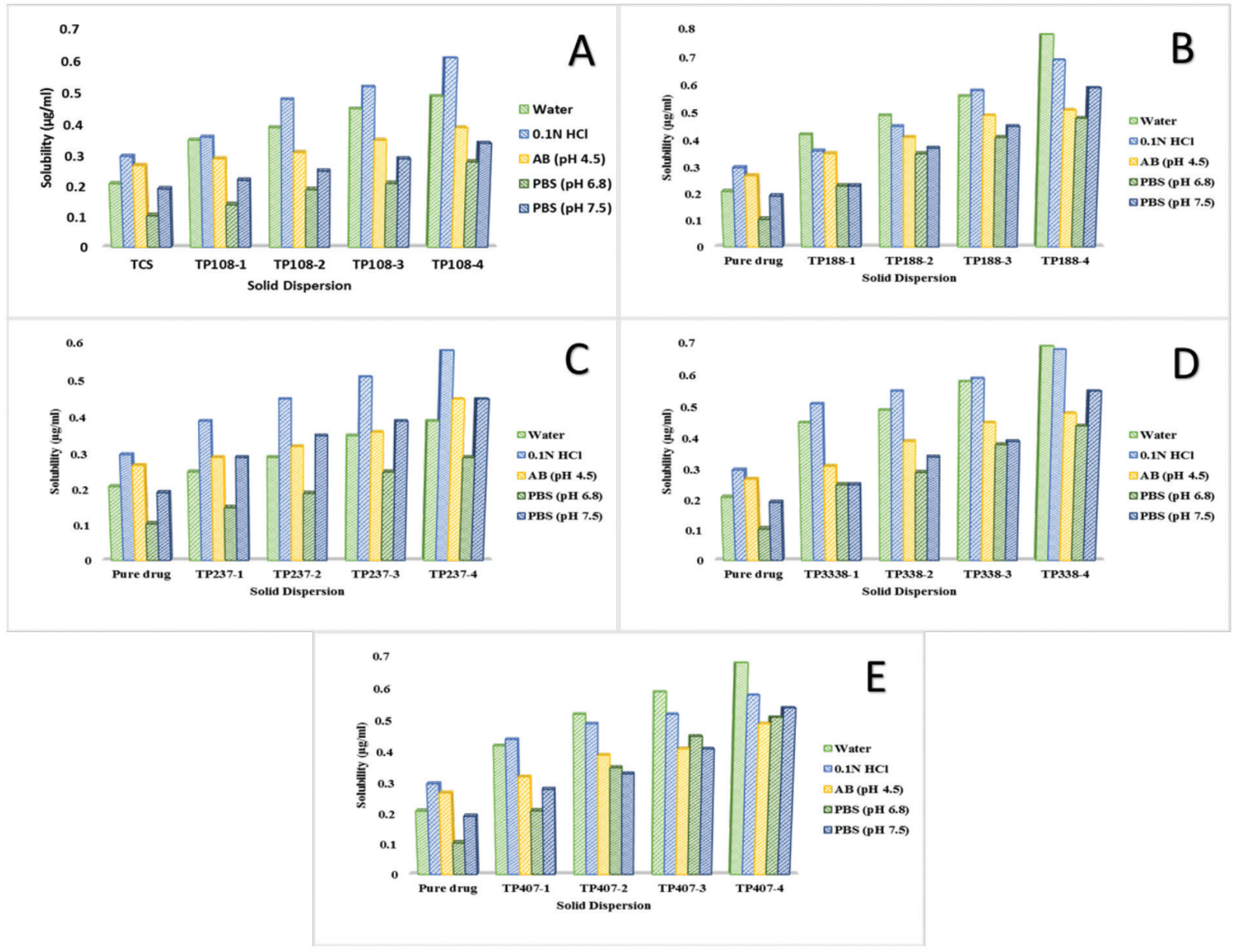

Figure 3. Solubility of thiocolchicoside and solid dispersions in various media with A) poloxamer-108; B) poloxamer-188; C) poloxamer-237; D) poloxamer-338; E) poloxamer-407 TCS: Thiocolchicoside

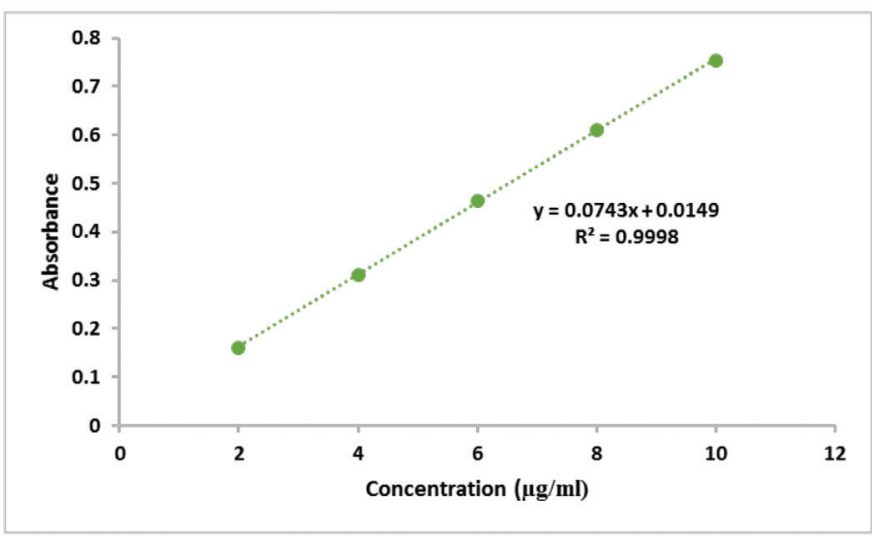

Figure 4. Calibration curve for the estimation of thiocolchicoside

$\mathrm{pH} 7.4$ phosphate buffer. The solubility in these was $\langle 0.3 \mu \mathrm{g} / \mathrm{mL}$, indicating poor solubility of the drug.

The SD tablets with poloxamer-108 (TP108-1, TP108-2, TP1083, and TP108-4) showed good solubility in $0.1 \mathrm{~N} \mathrm{HCl}$ (up to $0.61 \pm 0.05 \mu \mathrm{g} / \mathrm{mL}$ ) and in DW (up to $0.49 \pm 0.03 \mu \mathrm{g} / \mathrm{mL}$ ). The tablets with poloxamer-188 (TP188-1, TP188-2, TP188-3, and
TP188-4) showed good solubility in DW (up to $0.78 \pm 0.04 \mu \mathrm{g} /$ $\mathrm{mL}$ ) and in $0.1 \mathrm{~N} \mathrm{HCl}$ (up to $0.69 \pm 0.05 \mu \mathrm{g} / \mathrm{mL}$ ). The SDs tablets with poloxamer P-237 (TP237-1, TP237-2, TP237-3, and TP2374) showed good solubility in $0.1 \mathrm{~N} \mathrm{HCl}$ (up to $0.58 \pm 0.04 \mu \mathrm{g} /$ $\mathrm{mL}$ ) and in acetate buffer ( $\mathrm{pH}$ 6.8) (up to $0.45 \pm 0.03 \mu \mathrm{g} / \mathrm{mL}$ ). The tablets with poloxamer-338 (TP338-1, TP338-2, TP338-3, and TP338-4) showed good solubility in DW (up to $0.69 \pm 0.04$ $\mu \mathrm{g} / \mathrm{mL}$ ) and in $0.1 \mathrm{~N} \mathrm{HCl}$ (up to $0.68 \pm 0.05 \mu \mathrm{g} / \mathrm{mL}$ ). The tablets with poloxamer-407 (TP407-1, TP407-2, TP407-3, and TP4074) showed good solubility in $\mathrm{DW}$ (up to $0.68 \pm 0.05 \mu \mathrm{g} / \mathrm{mL}$ ) and in $0.1 \mathrm{M} \mathrm{HCl}$ (up to $0.58 \pm 0.03 \mu \mathrm{g} / \mathrm{mL}$ ). The nonionic surfactant component of poloxamer enhances the solubility of TCS in solvents. ${ }^{32,33}$

TCS followed the Beer-lambert law at the concentration of 2 to $10 \mu \mathrm{g} / \mathrm{mL}$. The regression produced $R^{2}=0.9998$; slope $=0.0743 x+0.0149$. The dissolution of the tablets was good in a lot of TCS:poloxamer (1:6) with all carriers, i.e. poloxamer-108, poloxamer-188, poloxamer-237, poloxamer-338, and poloxamer-407.

Furthermore, the hydrophilic polyoxyethylene part of the copolymer prevented aggregation of individual drug particles, 

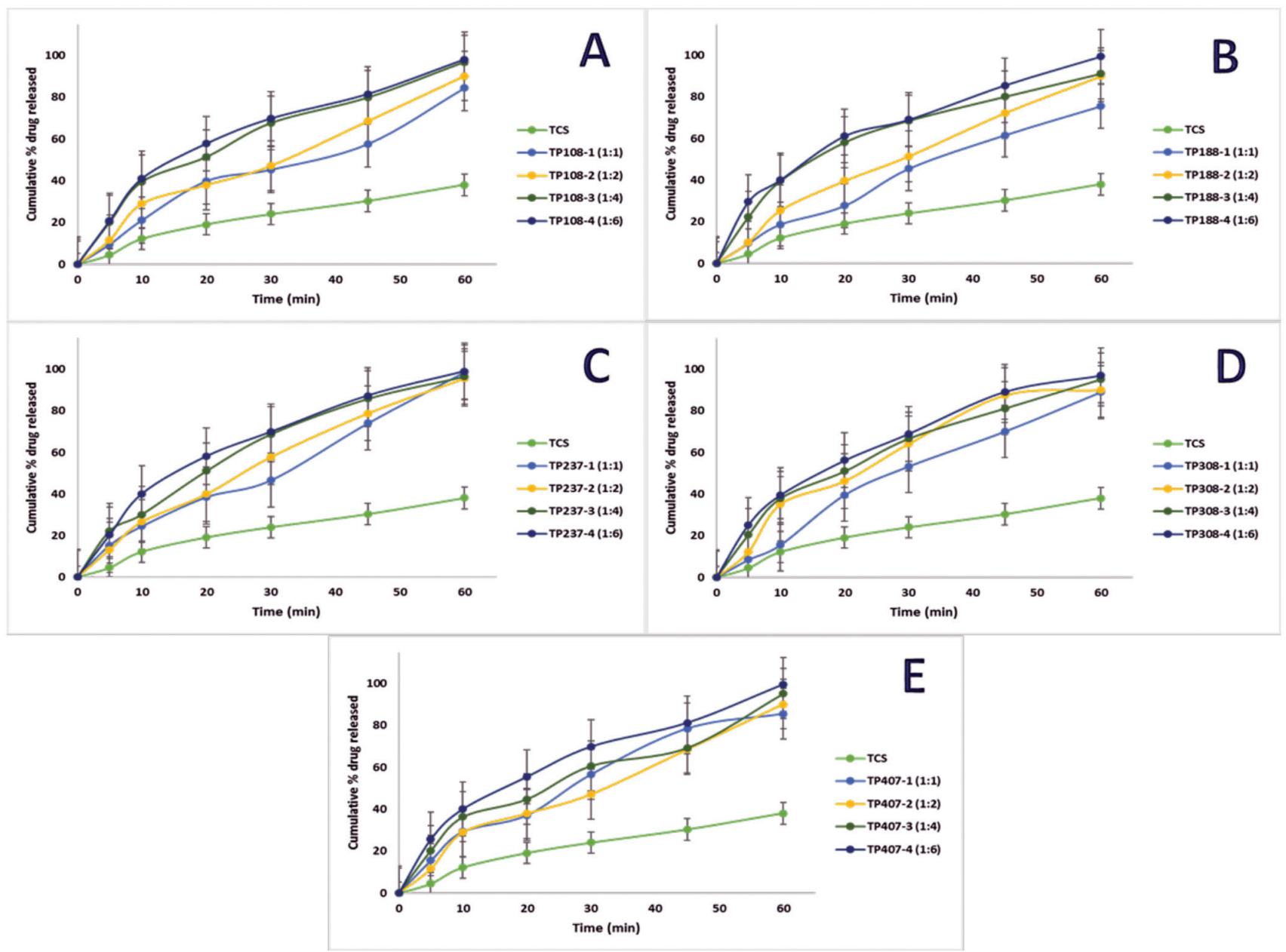

Figure 5. In vitro drug dissolution plots of thiocolchicoside solid dispersions with A) poloxamer-108; B) poloxamer-188; C) poloxamer-237; D) poloxamer-338; E) poloxamer-407

TCS: Thiocolchicoside

Table 5. Correlation coefficients $\left(R^{2}\right)$ for different release kinetics of thiocolchicoside solid dispersions

\begin{tabular}{llll} 
Correlation $\left(\mathrm{R}^{2}\right)$ & & & \\
\hline Formulation & Zero order & First order & Hixson-Crowell \\
\hline TP108-4 & 0.9738 & 0.9936 & 0.9979 \\
\hline TP188-4 & 0.5025 & 0.9885 & 0.9868 \\
\hline TP237-4 & 0.8823 & 0.9494 & 0.9206 \\
\hline TP338-4 & 0.9785 & 0.9868 & 0.9860 \\
\hline TP407-4 & 0.9738 & 0.9666 & 0.9804 \\
\hline
\end{tabular}

exhibiting high solid-liquid surface tension. Hence, it acted on the hydrodynamic layer adjacent to the TCS particles, resulting in an in situ inclusion progression that augmented dissolution. Similar observations have been reported for SDs by Viraj and Praveen. ${ }^{34}$

The regression gave $\mathrm{R}^{2}=0.9930,0.9869,0.9868,0.8869$ and 0.9980 for the first-order plots and 0.9979, 0.9868, 0.9206, 0.9860 and 0.9804 for the Hixson-Crowell models for formulations TP108-4, TP188-4, TP237-4, TP338-4, and TP407-

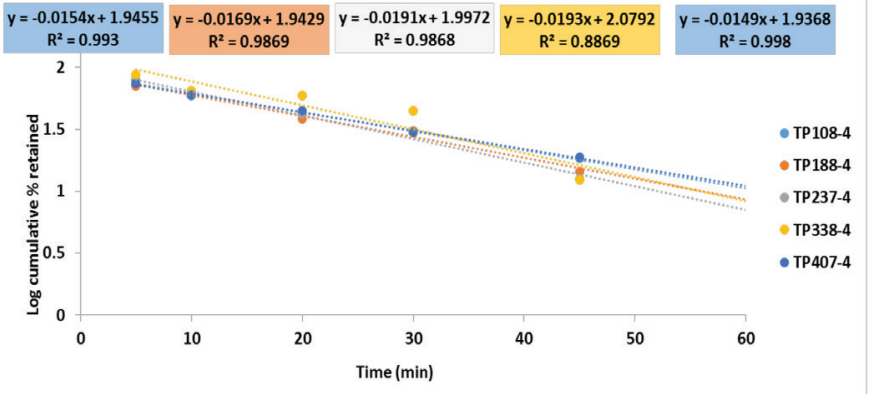

Figure 6. First-order plots for formulations with the drug:carrier ratio 1:6

4. Accelerated stability studies for the optimized formulation (TP188-4) revealed that these formulations retained their physical parameters even after extreme storage environments.

\section{CONCLUSION}

The attempt at elevating solubility was successful using various poloxamer carriers in 1:6 ratios of drug and carrier (TP108-4, TP188-4, TP237-4, TP338-4, and TP407-4) by making them into SD formulations. The MWF method was better than the 
other techniques of making SDs as MWF enables the exposure of drug and polymers to a uniform temperature and prevents overheating. TCS and poloxamer interactions studied using DSC and FTIR confirmed the suitability of polymer carrier with TCS. All the SDs were found to raise the solubility of TCS. Among the SDs the preparations with 1:6 ratios of TCS and poloxamer-188 (TP188-4) had better solubility and drug dissolution constraints compared to poloxamer-108, poloxamer-237, poloxamer-338, and poloxamer-407. This advance in formulation technology, $M W F$, is better than other conventional SDs preparation

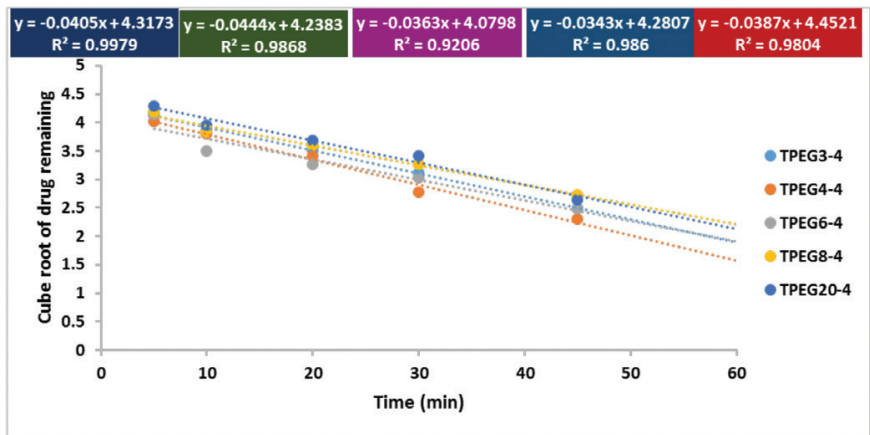

Figure 7. Hixson-Crowell plots for formulations with the drug:carrier ratio $1: 6$

techniques in terms of preparation and drug release. Hence we can conclude that poloxamer-188 is a better poloxamer carrier compared to poloxamer-108, poloxamer-237, poloxamer-338, and poloxamer-407 for preparing TCS SDs.

\section{ACKNOWLEDGMENTS}

The authors are thankful to Prof. N. Devanna, director, JNTUAOTPRI, Ananthapuramu, AP, India, for providing lab facilities for doing this research work.

Conflicts of interest: No conflict of interest was declared by the authors. The authors alone are responsible for the content and writing of the paper.

\section{REFERENCES}

1. Den Mooter GV. The use of amorphous solid dispersions: a formulation strategy to overcome poor solubility and dissolution rate. Drug Discovery Today Technologies. 2011;9:79-85.

2. Tüzün $F$, Unalan $H$, Oner $N$, Ozgüzel $H$, Kirazli $Y$, Içağasioğlu $A$, Kuran B, Tüzün S, Başar G. Multicenter, randomized, double-blinded, placebocontrolled trial of Thiocolchicoside in acute low back pain. Joint Bone Spine. 2003;70:356-361.

3. Soonawalla DF, Joshi N. Efficacy of Thiocolchicoside in Indian patients suffering from low back pain associated with muscle spasm. J Indian Med Assoc. 2008;106:331-335.

4. Maryadele J. The Merck Index; Thirteenth edition; Merck \& Co Inc. White house Station, NJ, USA; 2001:1662-1663.

5. Janbroers JM. Review of the toxicology, PD and PK of Thiocolchicoside, a GABA-agonist muscle-relaxant with anti-inflammatory and analgesic actions. Acta Ther. 1987;13:221-250.
6. Zawar L, Bari S. Microwave induced solid dispersion as a novel technique for enhancing dissolution rate of Repaglinide. Adv Pharmacol Pharm. 2013;1:95-101.

7. Moneghini M, Bellich B, Baxa P, Princivalle F. Microwave generated solid dispersions containing Ibuprofen. Int J Pharm. 2008;361:125-130.

8. Rashmika B, Veena V, Kachhwaha S, Bhikshapathi DVRN. Formulation development and in vivo evaluation of Fexofenadine $\mathrm{HCl}$ solid dispersions by spray drying technique. Der Pharmacia Lettre. 2013;5:73-82.

9. Xifeng Zhai, Li C,Lenon GB, Xue CCL, Li W. Preparation and characterisation of solid dispersions of tanshinone IIA, cryptotanshinone and total tanshinones. Asian J of Pharm Sci. 2017;12:85-97.

10. Orlandi S, Priotti J, Diogo HP, Leonardi D, Salomon CJ, Nunes TG. Structural Elucidation of Poloxamer 237 and Poloxamer 237/ Praziquantel Solid Dispersions: Impact of Poly (Vinylpyrrolidone) over Drug Recrystallization and Dissolution. AAPS Pharm Sci Tech. 2018;19:1274-1286.

11. Moneghini M, Zordi N, Grassi M, Zingone G. Sustained-release solid dispersions of ibuprofen prepared by microwave irradiation. Journal of Drug Delivery Science and Technology. 2008;18:327-333.

12. Seetha D, Peddnti D, Pinnika A. Formulation and evaluation of solid dispersion tablets of poorly water soluble drug candesartan cilexetil using poloxamer 407. Int $\mathrm{J}$ of Pharm Sci Review and Research. 2014:29:67-73.

13. Zhao Y, Xin T, Ye T, Yang X, Pan W. Solid dispersion in the development of a Nimodipine delayed-release tablet formulation. Asian J Pharm Sci. 2014;9:35-41

14. Papadimitriou SA, Bikiaris DN, Avgoustakis K. Microwave-Induced Enhancement of the Dissolution Rate of Poorly Water-Soluble Tibolone from Poly (ethylene glycol) Solid Dispersions. Journal of Applied Polymer Science. 2008;108:1249-1258

15. Mourya D, Belamwar V, Tekade A. Microwave induced solubility enhancement of poorly water soluble atorvastatin calcium. J Pharm Pharmacol. 2010;62:1599-1606.

16. Martin A. Physical Pharmacy. $4^{\text {th }}$ ed. Maryland, USA: Lippincott Williams and Wilkins; 1991:423.

17. Shah RB, Tawakkul MA, Khan MA. Comparative evaluation of flow for pharmaceutical powders and granules. Aaps Pharmscitech. 2008;9:250258.

18. Chiou WL, Riegelman S. Preparation and dissolution characteristics of several fast-release solid dispersions of Griseofulvin. J Pharm Sci. $1969 ; 58 ; 1505-1510$

19. Gu B, Linehan B, Tseng YC. Optimization of the Buchi B-90 sprays drying process using a central composite design for preparation of solid dispersions. Int J Pharm. 2015;491:208-217.

20. Annepogu H, Hindustan AA, Devanna N. Assessing the best polyvinyl pyrrolidone as a carrier for Etoricoxib solid Dispersions: fabrication and evaluation, J Pharm Sci Innov. 2018;7:208-214.

21. Lachman L, Liberman HA, Kanig JL The Theory and Practice of Industrial Pharmacy. Philadelphia, PA: Lea and Febiger; 1987:317-318.

22. Faheem B, Ahad HA, Shameena S, Asif M, Meena M, Abdul Riyaz S. Determining the Best Poly Ethylene Glycol as Solid Dispersion Carrier for Improvement of Solubility and Dissolution Rate of Ofloxacin. Int J Chem Pharm Sci. 2017;5:72-76. 
23. Annapurna MM, Priya NK, Anusha N, Purneshwar PB. New derivative spectrophotometric methods for the determination of thiocolchicoside - A semisynthetic derivative of colchicoside, International Journal of Green Pharmacy. 2018;12(Suppl):149-153.

24. Ayman A. Spectrophotometric and spectrofluorometric methods for the determination of NSAIDs. Arabian J Chemistry. 2013;6:145-163.

25. Indian Pharmacopoeia, Volume III; Government of India, Ministry of Health \& Family Welfare; the Indian Pharmacopoeia Commission; Ghaziabad. 2010:2213.

26. Chen ZP, Sun J, Chen HX, Xiao YY, Liu D, Chen J, Cai H, Cai BC. Comparative pharmacokinetics and bioavailability studies of quercetin, kaempferol and isorhamnetin after oral administration of Ginkgo biloba extracts, Ginkgo biloba extract phospholipid complexes and Ginkgo biloba extract solid dispersions in rats. Fitoterapia. 2010;81:1045-1052.

27. Lheritier AC, Abramovici JM. Improvement of the dissolution kinetics of SR 33557 by means of solid dispersions containing PEG 6000. International Journal of Pharmaceutics. 1995;123:273-279.

28. Remunan C, Bretal MJ, Nunez A, Jato JV. Accelerated stability of sustained release tablet prepared with Gelucire. Int J Pharm. 1992;80:151159.
29. Daniel JSP, Veronez IP, Rodrigues LL, Trevisan MG, Garcia JS. Risperidone-solid-state characterization and pharmaceutical compatibility using thermal and non-thermal techniques. Thermochimica Acta. 2013;568:148-155.

30. Kolasinac N, Kachrimanis K, Homsek I, Grujic B, Duric Z, Ibric S. Solubility enhancement of desloratadine by solid dispersion in poloxamers. Int $\mathrm{J}$ Pharm. 2012;436:161-170.

31. Veronez IP, Daniel JSP, Junior CEC, Garcia JS, Trevisan MG. Development, characterization, and stability studies of ethinyl estradiol solid dispersion. J Therm Anal Calorim. 2014;120:573-581.

32. Suhagia BN, Patel HM, Shah SA, Rathod I, Parmar VK. Preparation and characterization of Etoricoxib-polyethylene glycol 4000 plus polyvinyl pyrrolidone K30 solid dispersions. Acta Pharm. 2006;56:285-298.

33. Barzegar-Jalalia M, Valizadeha $H$, Dastmalchi $S$, Shadbada MRS, Barzegar-Jalalie A, Adibkiaa K, Mohammadia G. Enhancing dissolution rate of Carbamazepine via co-grinding with crospovidone and hydroxypropylmethylcellulose. Iranian J Pharm Res. 2007;6:159-165.

34. Viraj VK, Praveen DC. Characterization of Etoricoxib Solid Dispersions Prepared By Spray Drying Technique. Research J Pharm and Tech.2010;3:1158-1166. 